\title{
Az egészségturizmus fogalomrendszerének modellezése kiválasztott nyugat-dunántúli fürdôtelepülések mintáján keresztül
}

\section{Simulation of Health Tourism Concepts via a Sample of Spa Towns in Western Transdanubia}

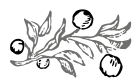

\section{Összefoglalás}

A tanulmány az egészségturizmus spektrumát vizsgálja, kiemelten kezeli a termál- és gyógyvízhez kötôdô részét. A témához kapcsolódó nemzetközi és hazai szakirodalmi áttekintés eredményeként létrejövô elméleti modellt teszteltük kiválasztott nyugat-dunántúli fürdôtelepüléseken. A mintatelepülések vizsgálatakor az elérhetô legfontosabb objektív adatokat értékeltük, megfigyeléseket végeztünk, szakmai mélyinterjúkat folytattunk a fürdókben és szálláshelyeken. Korábbi nemzetközi és hazai elemzéseket áttanulmányozva feltételeztük, hogy a fürdôtelepüléseken a fürdókomplexumok, a

Printz-Markó Erzsébet, tanársegéd, Széchenyi István Egyetem, doktorjelölt, Széchenyi István Egyetem, Regionális- és Gazdaságtudományi Doktori Iskola (printz-marko.erzsebet@sze.hu), Albert Tóth Aтtila, tanársegéd, Széchenyi István Egyetem, doktorjelölt, Széchenyi István Egyetem, Regionális- és Gazdaságtudományi Doktori Iskola (albert.toth.attila@sze.hu) 
Printz-Markó Erzsébet-Albert Tóth Attila: Az egészségturizmus fogalomrendszerének...

gyógy-, wellness-szállodák és más szálláshelyek múködése, fejlesztése egymásra kedvezó szinergiahatást gyakorolnak. A kutatás igazolta feltevéseinket: a fürdôtelepülések szálláshelyei és fürdốkomplexumai hatással vannak egymás, valamint a település fejlôdési útjára.

Journal of Economic Literature (JEL) kódok: L83, O18

Kulcsszavak: egészségturizmus rendszermodell, fürdôtelepülés, fürdôkomplexum, szálláshely

\section{Summary}

The study examines health tourism with special emphasis on spas. We tested the theory resulting from an overview of the international and Hungarian literature on selected spa towns in Western Transdanubia. The most important objective data available were evaluated and observations and deep interviews were made at the spas and accommodations. Having studied international and Hungarian analyses, we presumed that the operation and development of spa complexes, medicinal and wellness hotels and other accommodations at spa towns have beneficial synergies. The research proved our assumptions: the accommodations and spa complexes at spa towns affect each other as well as town development.

Journal of Economic Literature (JEL) codes: L83, O18

Keywords: health tourism system model, spa town, spa complex, accommodation

\section{KUTATÁSI SAROKPONTOK}

A gyorsan változó, kifinomult fogyasztói igényekhez való alkalmazkodás része az elméleti rendszerek aktualizálása. A magyarországi egészségturizmus keresletét és kínálatát a hazai adottságokon túlmenően nagymértékben alakítják a nemzetközi trendek is. Ennek értelmében egyre inkább megfigyelhetô az a holisztikus megközelítés, amely a test-lélek-szellem egységének beágyazódását jelenti a szolgáltatási és terminológiai modellekbe.

Az egészségturizmus összetett fogalom, mivel az egészségügy és a turizmus szolgáltatásait ötvözi (Bywater, 1990; Porter et al., 2006; Kincses et al.; 2009; Molnár, 2011) valamint a test-lélek-szellem egyensúlyára törekszik (Dunn, 1959; Rátz, 2004; AlbelTokaji, 2006; Ruszinkó, 2006; Aquaprofit, 2007; Smith-Puczkó, 2010; Sziva, 2010; Molnár, 2011; Resiak-Urbanowicz és Printz-Markó, 2011; Michalkó, 2012; Kenney, 2015; Printz-Markó et al., 2017). Ennek kapcsán fogalmazódott meg az igény az egyes elméleti modellek szintetizálására az igénybe vett egészségügyi és turisztikai szolgáltatások arányában, illetve a test-lélek-szellem egységének hangsúlyozásában az egészségturizmus alkotóelemeire vonatkozóan. Rendszermodellünk tesztelésére vonatkozóan három olyan nyugat-dunántúli települést választottunk, amelyek fürdôlétesítménnyel 
rendelkeznek. A vizsgálat a fürdők által kínált szolgáltatások egyfajta számbavételét jelenti. Amennyiben az egészségturizmus alszektorainak kínálati elemei döntô hányadban megjelennek a vizsgált létesítményekben, akkor feltételezhetô, hogy a modell beépíthetô a hazai egészségturizmus rendszerébe.

\section{A vizsgálatba bevont fürdôtelepülések, -létesítmények kiválasztásának kritériumai}

A kutatásba bevont helyszínek kiválasztását ötszúrôs szempontrendszer mentén határoztuk meg. Elsố tényezôként szerepelt, hogy az Országos egészségturizmus-fejlesztési stratégia (OES) szerinti három fố kategóriából (1. nemzetközi jelentőségú fürdôhelyek, történelmi, múemléki fürdôk, gyógyhelyek; 2. országos és regionális jelentôségú turisztikai szolgáltatók; 3. helyi jelentôségú fürdôk) egy-egy fürdôtípus képviseltetve legyen a mintában (Aquaprofit, 2007). Második befolyásoló elemnek számított, hogy az adott fürdőlétesítmény közvetlen összeköttetésben álljon egy szálláslehetôséggel. Ezt követte, hogy a fürdó egész éves nyitvatartással rendelkezzen. Negyedik kritériumként szerepelt, hogy kínálati skálája lefedje az egyes korosztályok igényeit, azaz többgenerációs fürdôként funkcionáljon az adott létesítmény. Ennél a szempontnál figyelembe vettük a Budai-Székács- és az Árpási-féle egészségturisztikai célcsoportokat: aktív fiatalok, szórakozást keresố fiatalok, egészségtudatos fiatalok, fiatal párok kisgyermekkel, családos középkorúak, egészségmegôrző középkorúak, egészségtudatos idősek, mútét utáni rehabilitációra szorulók, gyógyulni vágyó idôsek, nagyszülők unokákkal (Budai-Székács, 2004; Árpási, 2012). Ötödik szempontként lényegesnek tartottuk, hogy az adott fürdôlétesítményt könnyen elérhessük személyes helyszínbejárás és tapasztalatgyújtés céljából. Mivel állandó lakhelyünk, Mosonmagyaróvár és Gyoór, illetve a nyugat-dunántúli régió kiemelkedố kínálattal, gazdasági mutatókkal rendelkezik, ezért irányított mintavételi helyszíneink a soron következôk lettek: Lipóti Termál- és Élményfürdô; ${ }^{1}$ bükfürdôi Gyógy- és Élménycentrum, ${ }^{2}$ valamint kehidakustányi Kehida Termál-, Gyógy- és Élményfürdô. ${ }^{3} \mathrm{~A}$ három fürdôhely fôbb jellemzôit, ismertetôjegyeit a melléklet tartalmazza.

\section{Az egészségTURIZMUS MEgHATÁrozÁsA}

A Turisztikai Szervezetek Nemzetközi Uniója ${ }^{4}$ 1973-as definíciója szerint az egészségturizmus „...az ország természeti erôforrásait, de különösen a gyógyvizeket és az éghajlati adottságokat hasznosító egészségügyi létesítmények kiaknázása” (Smith-Puczkó 2010:19). Az Európai Fürdőszövetség ${ }^{5}$ szerint az egészségturizmus olyan üdülőterületekre történố pihentetô utazást jelent, amely során egészségfejlesztô ajánlatokat és módszereket lehet igénybe venni például egy gyógyfürdőben vagy gyógyhelyen (Kirschner, 2005).

Az egészségturizmus magyar sajátosságokkal átitatott meghatározására 2005-ben, a II. Nemzeti Fejlesztési Terv (II. NFT) elôkészítése során került sor. A definíció alapján az egészségturizmus a turizmusnak azon formáját jelenti, ahol a „turista utazásának fố motivációja az egészségi állapotának javítása és/vagy megốrzése, tehát a gyógyulás és/vagy a megelôzés, és ennek megfelelóen a célterületen tartózkodása alatt igénybe is vesz egész- 
Printz-Markó Erzsébet-Albert Tóth Attila: Az egészségturizmus fogalomrendszerének...

ségturisztikai szolgáltatás(oka)t" (Aquaprofit, 2007:9). Ennek értelmében az egészségturizmus alappillérei a gyógyturizmus és wellnessturizmus (Rátz, 2004; Albel-Tokaji, 2006; Ruszinkó, 2006; Michalkó, 2012). Smith-Puczkó (2010) megközelítésében az egészségturizmus részei az alábbiak: szabadidô- és rekreációs turizmus, spaturizmus, thalassoturizmus, spirituális turizmus, holisztikus turizmus, jóga- és meditációs turizmus, munkához kapcsolódó wellness- és a gyógyturizmus két fô formája: sebészeti és terápiás gyógyturizmus. Az egészségturizmushoz kapcsolódó elméletek összegzését tartalmazza az 1. ábra.

\section{1. ábra: Az egészségturizmus értelmezése}

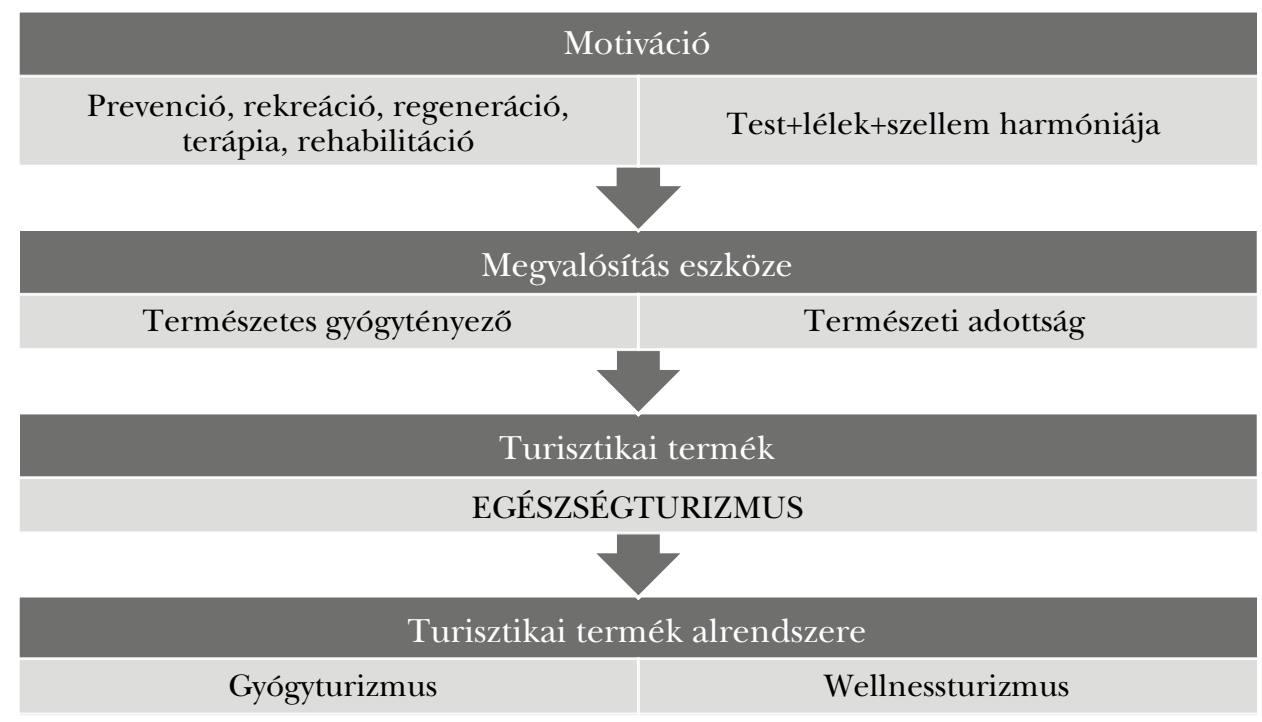

Forrás: Saját szerkesztés Resiak-Urbanowicz-Printz-Markó, 2011 alapján

Az 1. ábra „input-output” nézópontból rendszerezi az egészségturizmust, mely szerint a motiváció és a megvalósításhoz szükséges természet alkotta erôforrások eredménye. Ez az értelmezés nem tartalmazza a diszkrecionális jövedelmet, a szabadidôt és az ember alkotta erőforrásokat. Az ember alkotta mesterséges eróforrások is a megvalósítás fontos eszközei, idetartoznak a termál- és gyógyfürdók, egyéb fürdôtípusok, illetve egészségügyi intézmények (Czeglédi, 1999), wellnesscentrumok, gyógyszállodák, wellness-szállodák (Voleszák, 2000), és minden további olyan egyéb létesítmény, amely az egészségturizmus vendégkörének igényeit kiszolgálja. A wellness-szállodák kialakulásának hátterében Michalkó szerint az áll, hogy a turizmus kiválóan felismerte, „a test, a lélek és a szellem optimumának elérését idóben és térben koncentráltan kell a vendég számára biztosítani” (Michalkó, 2012:180). A kifinomult fogyasztói igények kiszolgálásához elengedhetetlen a szakképzett emberi erőforrás. A turisták növekvô tudatosságát és a szolgáltatók egyre nagyobb képzettségi igényét hangsúlyozza az Albel-féle spapiramis-rendszer (Albel-Tokaji, 2006). Formádi (2008) a gazdálkodási, turisztikai és egészségügyi ismeretek, készségek meglétét hangsúlyozza. Matolcsy 
(Szántó, 2009) úgy gondolja, hogy az oktatás révén tudja hazánk felvenni a versenyt az elsôdleges konkurenseinkkel (például Ausztriával, Svájccal).

\section{Az EgészSÉgTURIZMUS NÉHÁNy RENDSZERMODELLJE}

Az egészségturizmus fó kutatási problémája Bywater megközelítésében az, „hogy ez a szektor az egészségügyhöz vagy a turizmushoz tartozik, illetôleg, hogy a kettő öszszekapcsolható-e, s ha igen, milyen mértékben" (Bywater, 1990:52). Ezen kérdéskör megvilágítását segíti Porter és diákjai (2006), a budapesti Egészségügyi Stratégiai és Kutatóintézet (ESKI) (2009), valamint Molnár (2011) fogalomértelmezése, illetve az ezekre épüló saját rendszermodellünk.

Porter és diákjai (2006) az ázsiai térség egészségügy- és turizmuskeresletét és -kínálatát vizsgálták a Thaiföld Egészségügyi Turizmus klaszterelemzésén keresztül. Rendszermodelljük elsôsorban a gyógy-/orvosi turizmushoz kapcsolódó kínálati elemeket tartalmazza. A skála egyik végpontja az egészségügyi, orvosi tevékenység kiszervezését jelenti, itt megnyilvánul az egészségügyhöz tartozó szolgáltatások dominanciája. Érezhetô az egyes eljárások szintjéhez kapcsolódó komplexitás és rizikó mértékének erôsödése, ezt támasztja alá, hogy a tartózkodás helyszíneként a szállodák mellett megjelennek a kórházak is. A skála másik végpontján a turizmushoz kapcsolódó szolgáltatások vannak túlsúlyban: az utazási csomagok turizmusszolgáltatásai között, kiegészítô elemként, egészségmegôrzô ajánlatokat is kialakítottak.

Az ESKI munkatársai (Kincses et al., 2009) az egészségügyi és a turizmusszolgáltatások igénybevételének mértéke alapján elsôként jelenítik meg a hazai egészségturizmus rendszerezésében az egészségügyi turizmust mint alszektort. Molnár (2011) megközelítésében az egészségturizmus két alkotóeleme a wellnessturizmus és a gyógyturizmus, amelyet harmadik pillérként kiegészít az e kettô metszeteként létrejövô, 2008-tól dinamikusan fejlôdô, németországi gyökerekkel rendelkezô medical wellness irányzat (Aquaprofit, 2007; Smith-Puczkó, 2010).

\section{AZ EGÉSZSÉGTURIZMUS RENDSZERMODELLÜNK ÉS ANNAK TESZTELÉSE}

A fenti rendszerek szintetizálásaként az egészségturizmust meghatározó két fố szolgáltatást az igénybevételi arányukkal és a holisztikus szemlélet szerint a test-lélek-szellem harmóniáját figyelembe vevő turizmustípusokkal modelleztük a 2. ábrán. Egyben azt is illusztráltuk, hogy az egészségturizmus altermékei közül melyek vehetôek igénybe, illetve jelenthetnek lehetôséget a jövooben a vizsgált fürdôk területén. Amennyiben a mintavételi helyszínek kínálata illeszkedik az elméleti modellünkhöz, akkor az alátámasztja annak alkalmazhatóságát. A rendszerezett egészségturizmus-spektrum gyakorlati tesztelésének céljából bejártuk a kutatásba bevont helyszíneket, és feltérképeztük szolgáltatási palettájukat. Az ábra méretarányosan érzékelteti az egészségügyi és turisztikai szolgáltatások igénybevételét, valamint a test-lélek-szellem dimenzióját az egészségturizmus típusainál. 
Printz-Markó Erzsébet-Albert Tóth Attila: Az egészségturizmus fogalomrendszerének...

Rendszermodellünk új tudományos hozzáadott értékét az adja, hogy az egészségügyi és turisztikai szolgáltatások igénybevételi aránya mellett (Bywater, 1990; Porter et al., 2006; ESKI, 2009; Molnár, 2011) egyértelmú és átlátható módon egyaránt súlyozza a test-lélek-szellem dimenzióját. Nemcsak a wellnessturizmusban, hanem a gyógyturizmusban is értelmezhetố ez az egység, hiszen adott terápia sikeréhez a gyógyulásba vetett hit is hozzájárul.

Az egyes dimenziók értelmezéséhez tartozik, hogy a test dimenziójához kapcsolódnak a fizikai cselekedeteink, a lélek dimenziójához az érzelmeink, a szellem dimenziójához pedig gondolkodásmódunk, hitrendszerünk. Ez utóbbi meghatározza az érzelmeinket, amelyek hatással vannak cselekedeteinkre. Betegségeink lelki gyökerekhez kapcsolódnak, ezért gyógyításukhoz, illetve egészségünk megőrzéséhez fontos ennek az egymásra épülô hármasságnak (test, lélek és szellem) a figyelembevétele. Gondolkodásmódunk, hitrendszerünk befolyásolja érdeklődési körünket, amely pozitív, illetve negatív érzéseket, információkat közvetít a testünk felé, esetünkben egy adott gyógykezeléshez vagy egészségmegőrzô technikához kapcsolódóan. Ezek az érzéseink, megtapasztalásaink irányítják cselekedeteinket, itt az attitúdünket az adott egészségturisztikai szolgáltatás igénybevételéhez.

Az egészségturizmus meghatározásait elemezve megállapítható, hogy a két alszektor, a gyógy- és a wellnessturizmus (Rátz, 2004; Albel-Tokaji, 2006; Ruszinkó, 2006; Michalkó, 2012) kínálata jelen van a mintavételi helyszíneken.

A gyógyturizmus spektrumát vizsgálva látható, hogy mindegyik fürdô minôsített gyógyvízzel rendelkezik. ${ }^{6}$ Bükfürdôn társadalombiztosítási támogatással is igénybe vehetôk a gyógykezelések, talán ezért is a három helyszín közül itt a legjelentôsebb a gyógyvízre épüló gyógyturizmus. Kehidakustány esetében nem, azonban orvosi felügyelet mellett kínálnak gyógykezeléseket (például súlyfürdókezelés).

A reprodukciós és a thalassoturizmus érintôlegesen kapcsolódhatnak a vizsgált fürdôkhöz. A bükfürdői gyógyvíz összetételének köszönhetően kiválóan alkalmas krónikus nôgyógyászati és urológiai gyulladások kezelésére. Ennek értelmében támogathatja a reprodukciós turizmust, illetve annak elôkészítési fázisát. A kutatási helyszínek esetében a thalassoturizmus elemzése erôltetettnek tûnhet, azonban ha figyelembe vesszük, hogy olyan kezelési eljárásokat is magában foglal, amelyekben tengervizet, tengeri algákat és a tenger sóját használják fel (Smith-Puczkó, 2010), akkor metszéspontot lehet felfedezni. A bükfürdôi thermo spa kezelések során thermo spa algapakolás, illetve thermo spa tengeri sós pakolás vehető igénybe, a kehidakustányi iszappakolás a holt-tengeri fekete iszappal valósul meg. A Nemzetközi Fürdôszövetség7 értelmezésében és a Spafinder megközelítésében (Rátz, 2004) a fürdôk a spák egyik típusát jelentik. Ebben a megközelítésben mindhárom mintavételi helyszín kapcsolódik a spaturizmushoz.

A gyógy-és wellnessturizmus metszéspontját jelenti a medical wellness (Aquaprofit, 2007; Smith-Puczkó, 2010). Ez Bükfürdô kínálatában fontos súlypont, hiszen külön medical wellness és medical fitness részleg múködik a fürdő területén. Kehidakustány esetében az orvosi vizsgálathoz kötött eljárások, a fiatalító-szépségápolási kozmetikai programok részeként értelmezhetô a medical wellness. 


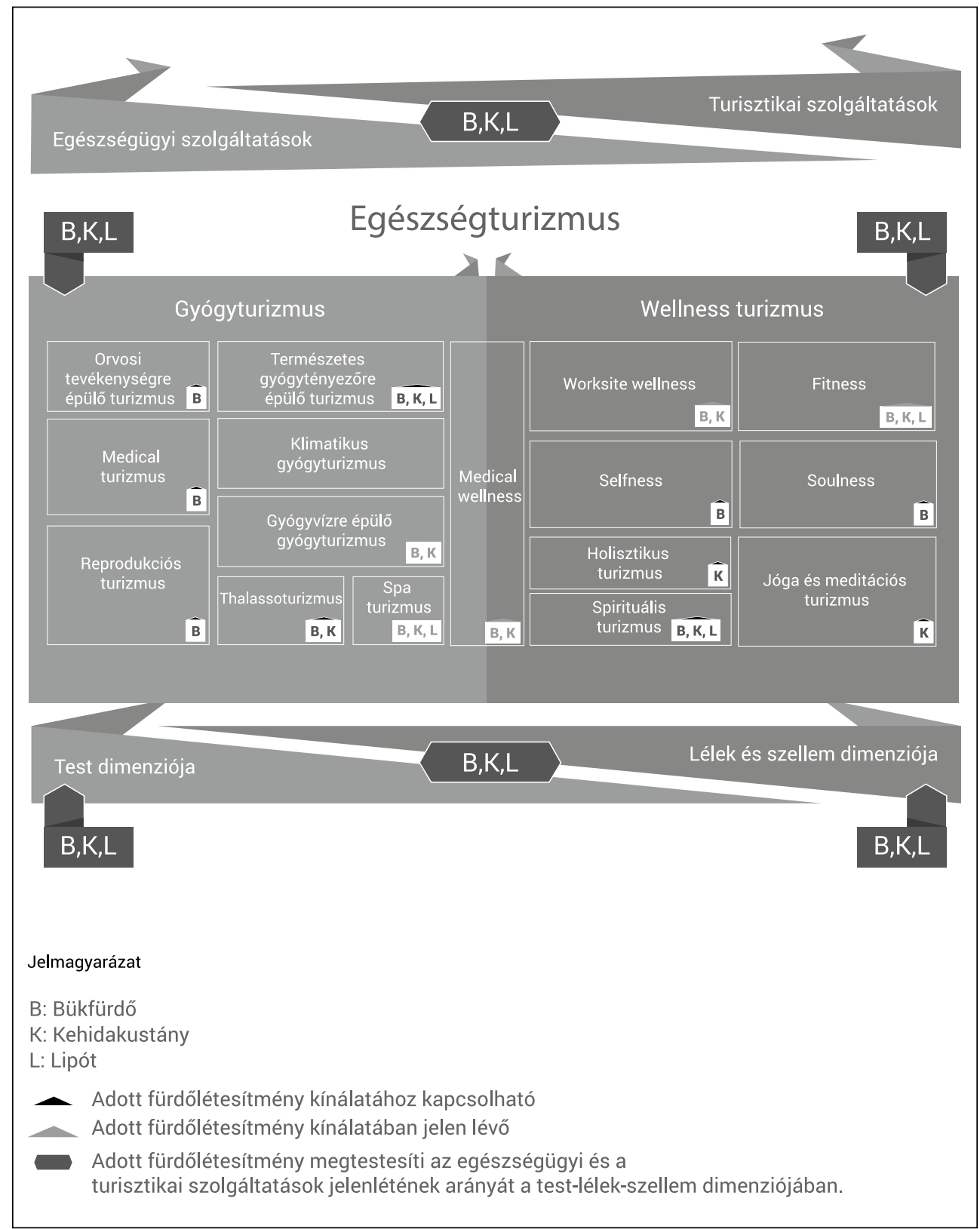

Forrás: Saját kutatás alapján saját szerkesztés

Aktív mozgáshoz kapcsolódó programok révén mindhárom fürdô kínálatában megjelenik a fitness. Bükfürdô esetében külön ki kell emelni, hogy a medical wellness, medical fitness részleg kiépítéséig külön Fitpoint üzemelt, amely egyéni állapot- 
Printz-Markó Erzsébet-Albert Tóth Attila: Az egészségturizmus fogalomrendszerének...

felmérésekre és programajánlásokra adott lehetôséget. Ennek értelmében a selfness is mint kapcsolódási pont határozható meg. A vizsgált fürdők mindegyike rendelkezik élménymedencével és a wellnesshez kapcsolódó kínálattal.

Bükfürdô és Kehidakustány SZÉP-kártya-elfogadóhely. Ebbôl következốn hozzájárul a hazai lakosság, a munkavállalók egészségmegórzéséhez. Tehát értelmezhetô a kínálati palettán a worksite wellness.

A spirituális turizmus része a spaközpontok felkeresése (Magyar, 2008). Amennyiben a fürdôkre mint „nedves kolostorokra” tekintünk (Márai, 1943), akkor a mintavételi helyszínek mindegyike kapcsolódhat ezen turizmusfajtához. Itt fontos megemlíteni egy olyan nyugat-dunántúli fürdôt, amely nem szerepel a mintában, azonban már jelenleg is szoros kapcsolódási pontot képez a fürdôzés és a spiritualitás között. A lenti fürdô különlegességét az adja, hogy a fürdô területén található a Szent György Energiapark. Egyedi módon itt nem két, hanem három jótékony földsugárzású energiavonal találkozik össze. Tehát Lenti egyértelmúen kapcsolódik a spirituális turizmushoz is. Az energiahelyek a testi-lelki fittség elérését segíthetik. A kehidakustányi fürdôlétesítmény esetében lehetôség a holisztikus-, jóga és meditációs turizmus. A desztináció kínálatának, valamint egy szélesebb látókörnek köszönhetôen kooperáció létesíthetô a Zalaszántói Béke Sztúpával. Elképzelésünk szerint a Peace Run (Békefutás) vagy egyéb, elsôsorban fizikai igénybevétellel járó programjaik záró, revitalizációs programeleme lehet a termálvízben történô fürdôzés.

Mivel a mintaterületek többgenerációs fürdôk, és egyszerre többféle fürdôkategóriát is magukban foglalnak (gyógyfürdô, élményfürdô, wellnessfürdô, strandfürdô), ezért kínálatukban az egészségturizmushoz kapcsolódó alszektorok szolgáltatási elemei is fellelhetôek, illetve a keresleteknek megfelelően fejleszthetôk. Tehát a kutatási helyszínek számos ponton kapcsolódnak a megfogalmazott egészségturizmus spektrumhoz.

\section{A VIZSGÁLT FÜRDốTELEPÜLÉSEK SZÁLLÁSHELYEINEK ÉRTÉKELÉSE}

A kutatásba vont három település szálláshelyeinek vizsgálata szoros összefüggésben van a fürdólétesítményekkel, hiszen ezek a szálláshelyek, a turisztikai szuprastruktúra fontos elemeként, lehetôvé teszik a vendégek hosszabb idejú tartózkodását, ezáltal a magasabb bevételtermelő képességet az adott településen. A viszonylag kisebb, alacsony állandó lakónépességú településeken a helyi lakosság és a regionális vonzáskörzetben élők, mint korlátozott potenciális vendégkör, hosszabb távon, fenntartható módon nem feltétlenül lenne elegendô a fürdôk nyereséges múködéséhez. A szálláshelyek biztosítják a lehetôséget, hogy a nagyobb távolságból érkezô turisták a település fơ vonzerejének számító fürdőben ne csak egy fürdőbelépoot, hanem komplex gyógyászati, egészségmegôrzô, wellness szolgáltatáscsomagot vegyenek igénybe, akár a fürdôkomplexumban, akár a gyógy- vagy wellness-szállodákban vagy más kategóriájú szálláshelyeken. Az olyan fürdôkomplexumoknál, ahol a fürdô és a szálloda egymás mellett található, és közvetlen átjárási lehetôség van közöttük, ott a gyógyászati szolgáltatások egy részét sok esetben a fürdőben biztosítják a vendégeknek, és a szálloda épületében ki sem építik a gyógyászati, wellness-szolgáltatások teljes vertikumát. Ez kölcsönös 
előnyöket nyújthat a fürdőnek és a szálláshelynek, de elsôsorban a vendégek számára előnyös, mert még a legkiválóbban felszerelt és kiépített gyógyszállodák sem mindig tudják azt a sokféle szolgáltatási lehetôséget biztosítani, ami egy fürdôkomplexumban rendelkezésre áll (Albert Tóth, 2011). A szálláshelyek munkahelyeket teremtenek a település lakóinak, a fürdók vendégeinek a számát is növelhetik a saját vendégeik által, és a helyi adók vonatkozásában is bevételt jelenthetnek a települések számára.

A vizsgált három település szálláshelyi kapacitásait és struktúráját elemezve megállapítható, hogy Bük kiemelkedik a mezónyból, ahol 18 szálláshelyen 1344 kiadható szoba található, míg Kehidakustányban 6 szálláshelyen 180 szoba, Lipóton 5 szálláshelyen 100 szoba várja a vendégeket. A büki szálláshelyek kínálata is a legváltozatosabb, 9 szállodából három minôsített négycsillagos szálloda, két minôsített gyógyszálloda (Danubius, Piroska) található a településen (ÁNTSZ, 2017a).

A gyógyszállodáknak már évszázados hagyományai vannak Magyarországon, különösen a fürdőtelepüléseken, de manapság ezeknek a szállodáknak is alkalmazkodni kell a kereslethez, a vendégek folyamatosan változó igényeihez. A gyógyszállodákra hagyományosan jellemzô balneoterápiás kezelések mellett már a prevenciós jellegú wellness-szolgáltatások nyújtása is fontossá vált. A wellness-szállodák egyre divatosabbak mindenhol a világon, így nálunk is, amelyek elsôsorban a megelôzésre és az élményre helyezik a hangsúlyt (Albert Tóth, 2016). Lényeges különbség a gyógy- és a wellness-szállodák között, hogy a wellness-szállodákban általában nincsen orvosi felügyelet melletti kezelés, ez csak a minôsített ötcsillagos wellness-szállodákban kötelezô kritérium, de ilyen minôsítésû szálloda nem található a három vizsgált településen. Mindegyik településen múködik panzió, üdülőház, és egyéb szálláshely kategóriába sorolható szálláshely, kempingek Bükön és Lipóton üzemelnek szezonális jelleggel. Érdemes kiemelni, hogy Bükön még országos szinten is jelentôs mennyiségú a kiadható férôhelykapacitás, amely 5366 féróhelyet jelent, ennek kicsit több, mint tíz százaléka található Lipóton és Kehidakustányban, ahol 629, illetve 541 férôhely áll rendelkezésre. Az éves szobakapacitás kihasználtsága szintén Bükön a legmagasabb, 68\%-os volt 2017-ben, míg ugyanez a mutató nem érte el az ötven százalékot Kehidakustányban (49\%) és Lipóton (46\%) (KSH, 2017).

A kapacitási adatokból következôen a vendégek és a vendégéjszakák száma is Bükön a legmagasabb, de az arányok is érdekesen alakultak az utóbbi tíz évben. A 3. ábrán a 2008 és 2017 közötti vendégéjszakaszámok láthatók, amelyból kitúnik, hogy Bükön a kapacitásarányoktól jelentôsen eltérôen, mintegy hússzorosa a vendégéjszakák száma a Lipótihoz képest, szinte minden évben. A fejlődés viszont mindegyik településen szembetûnô. A 2008-as évhez képest, Bükön 38\%-kal, Kehidakustányban 67\%-kal, Lipóton 92\%-kal sikerült növelni a vendégéjszakák számát 2017-ig. A külföldi és a belföldi vendégéjszakák aránya is eltérést mutat a három településen. A 2017-es évben Bükön $61 / 39 \%$, Kehidakustányban 27/73\%, Lipóton 38/62\% volt a külföldi és a belföldi vendégéjszakák aránya (KSH, 2017). A büki külföldi vendégéjszakák számának magasabb aránya a nagyon jó minôségú szállodáknak, a szállodavállalatok nemzetközi értékesítési és marketingmunkájának, a külföldi piacokon évtizedek alatt sikeresen bevezetett turisztikai desztinációnak és a jól múködő helyi TDM-szervezetnek is köszönhetô. 
Printz-Markó Erzsébet-Albert Tóth Attila: Az egészségturizmus fogalomrendszerének...

3. ábra: Vendégéjszakák számának alakulása a vizsgált településeken, 2008 és 2017 között

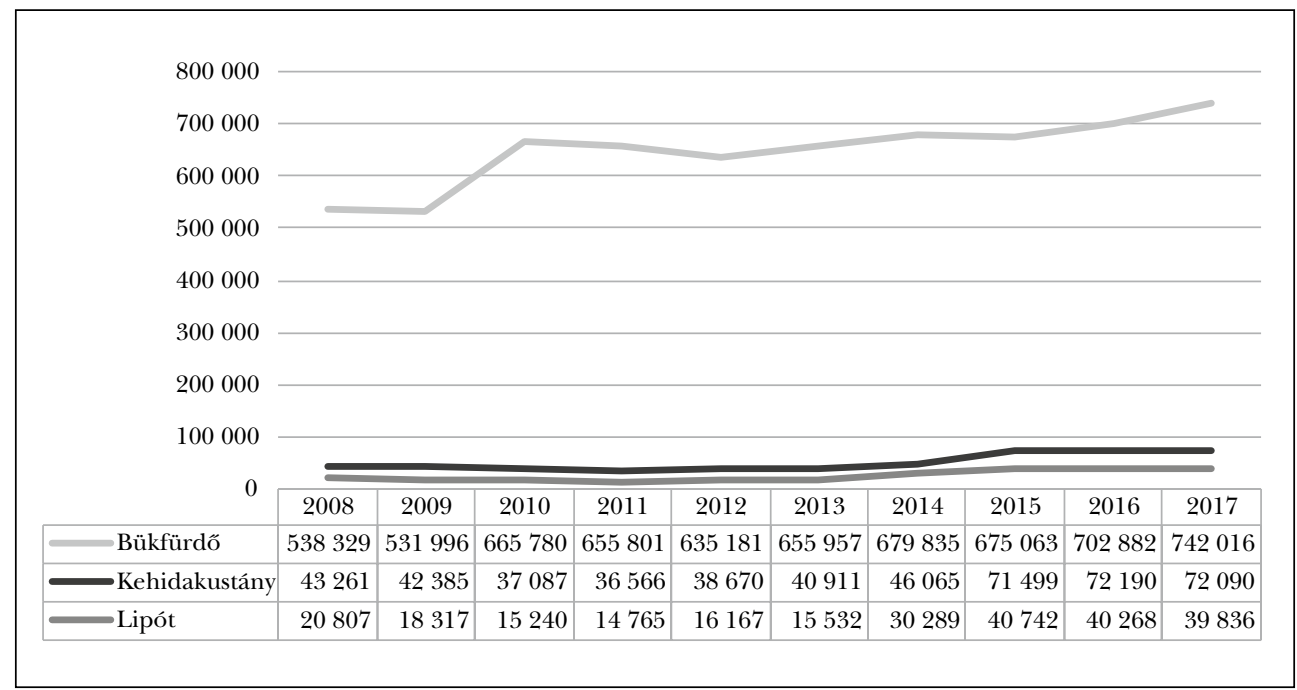

Forrás: Saját szerkesztés KSH-adatok alapján

A szállásdíjbevételek (4. ábra) tekintetében az arányok hasonlóak az elôzőekhez képest, de részleteiben vizsgálva, a büki fölény már olyan mértékú, amit majd késôbb az 5. ábra támaszt alá. A szállásdíjbevétel növekedés $62 \%$-os volt Bükön, 56\%-os Kehidakustányban és 126\%-os Lipóton 2008 és 2017 között.

Érdekes képet mutat a Széchenyi Pihenôkártya használatának mértéke a szálláshelyeken. A SZÉP-kártyával fizetett szállásdíjak aránya a belföldi forgalom 30\%-a volt Bükön, 56\%-a Kehidakustányban és mindössze 12\%-a Lipóton 2017-ben (KSH, 2018). A vendégek tartózkodása után befizetett idegenforgalmi adó mértéke 269 millió Ft volt Bükön, 21,7 millió Ft Kehidakustányban és 13,7 millió Ft Lipóton 2016ban. Ezek alapján Bük a 10. helyezést érte el a magyarországi települések között a beszedett idegenforgalmi adó mértékét illetôen, míg Kehidakustány a 80., Lipót a 105. lett az országos listán (Magyar Államkincstár, 2018). ${ }^{8}$

A szállodaiparban használatos mutatószámok (5. ábra) alapján már közvetlenül összehasonlíthatóak az egyes települések mutatói, kiküszöbölve az eltérô kapacitásokból adódó arányokat. Jól látható, hogy az egy vendégre, az egy vendégéjszakára jutó szállásdíjak már nem Bükön a legmagasabbak, ugyanígy a REVPAR-mutató ${ }^{9}$ és a kiadott szobák átlagára is Lipóton a legkedvezôbb.

Ezek a mutatószámok utalnak arra, hogy a vizsgált településeken a legkisebb kapacitásokkal rendelkezô és a legkevesebb vendégéjszakát realizáló Lipóton, a bevételi oldal tekintetében hatékonyabban üzemelnek a szálláshelyek. Magasabb átlagárakat tudnak elérni a kiadott szobáknál, amelyet ugyan az alacsonyabb foglaltsági mutató leront, de egy kivételével még így is megelôzi a másik két település mutatószámait. 
4. ábra: Szállásdíjbevételek alakulása a vizsgált településeken, 2008 és 2017 között (M Ft)

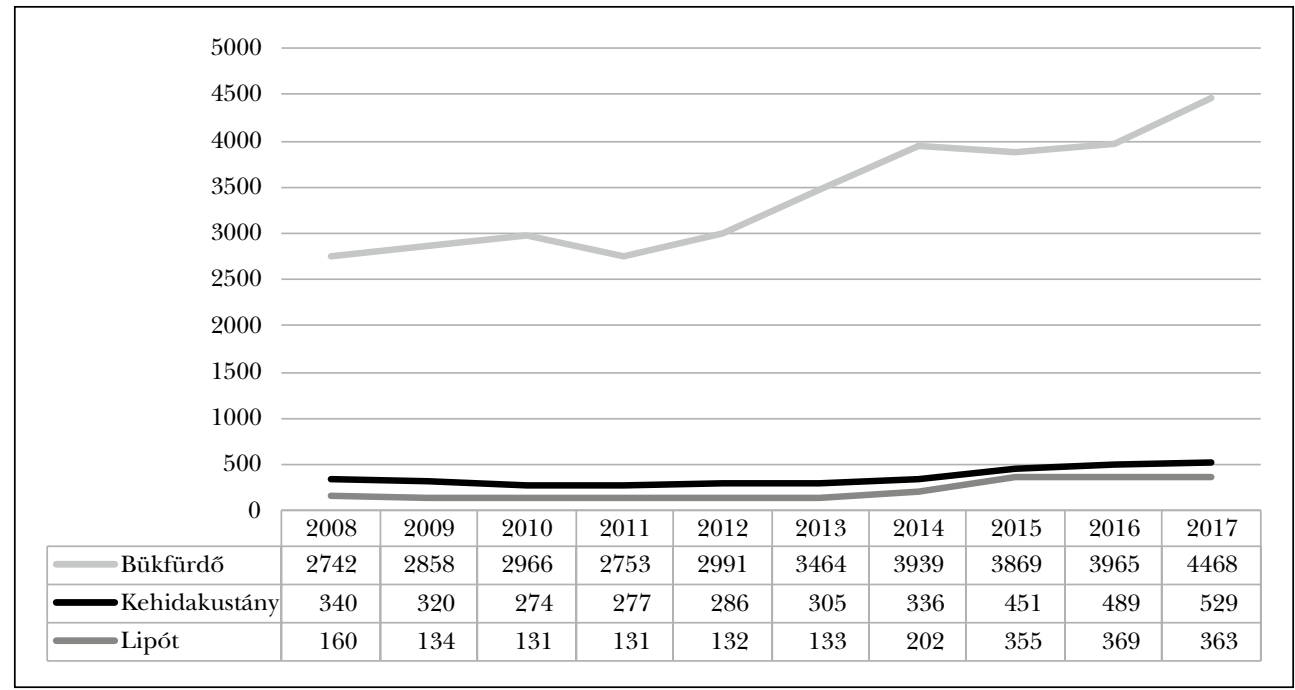

Forrás: Saját szerkesztés KSH-adatok alapján

5. ábra: Bevétellel kapcsolatos hatékonysági mutatószámok a vizsgált települések kereskedelmi szálláshelyein 2017-ben (Ft)

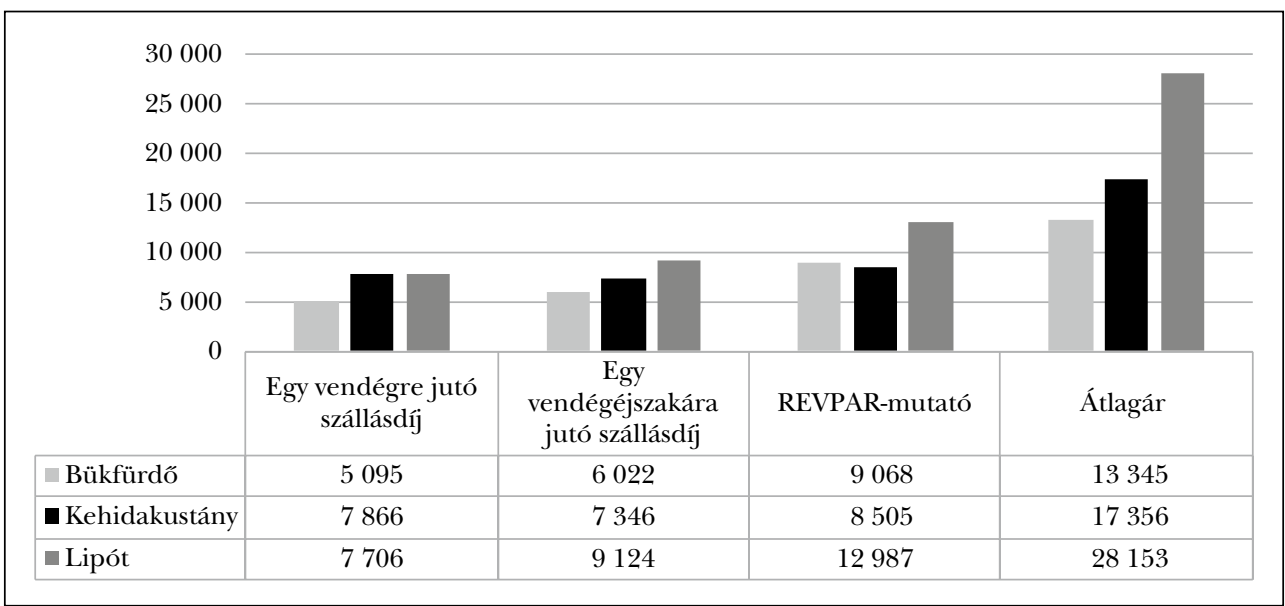

Forrás: Saját szerkesztés KSH-adatok alapján

\section{AZ EREDMÉNYEK ÖSSZEGZÉSE}

A tanulmány eredményei hasznosíthatók az egészségturizmus elméleti rendszerezéséhez, valamint gyakorlati összefüggések továbbgondolásához hozzájárulva, az egészségturizmus hatékonyabb pozicionálásához. A megközelítésünkben rendszerezett egészségturizmus-spektrum emberközpontú, intellektuális, spirituális, mentális és fizikális 
Printz-Markó Erzsébet-Albert Tóth Attila: Az egészségturizmus fogalomrendszerének...

szempontból egyaránt újszerúen rendszerezi az egészségturizmus fogalmait. Egyfajta visszacsatolást jelent a Dunn-féle wellnessfilozófiához (1959) a trendek (Kenney, 2015) figyelembevétele mellett.

Az egészségturizmus szektoraiban való elmélyülés, illetve a fürdôvendégek fogyasztói magatartásának elemzése segítséget jelenthet a wellness-szállodák fürdólátogató vendégei részére nyújtott szolgáltatások kialakításában is (Happ, 2008). Hiszen fontos árbevétel-növelô hatással rendelkezhet a fürdő területén vagy vele közvetlen összeköttetésben álló, akár csak kisebb kapacitású wellness-szálloda is (MundruczóSzennyessy, 2005). Mindez jól tükrözi az egészségturizmus üzletágához kapcsolódó szálláshelyfejlesztések és a további vonzerô- és szolgáltatásfejlesztések szinergiahatását (Mundruczó et al., 2010).

A fürdôtelepülések versenyképességi vizsgálatánál (Bakucz et al., 2016) megállapítják, hogy a minôségi szálláshelyek, szállodai beruházások hiánya lemaradáshoz vezethet, hátrányosan érintheti a településeket. A fürdőtelepülések szálláshelyei jelentôs mértékben hozzájárulnak az adott település turizmusához, a fürdókomplexumok sikeres múködéséhez, a terület fejlódéséhez.

Bük kiemelkedik a három vizsgált település közül a vendégéjszakák számának és a bevételek mértékének tekintetében, de a relatív mutatószámok, a hatékonyságot mérô mutatók már Kehidakustány és Lipót eredményességét, sikerét is igazolják. Mindegyik településen szükség van további összehangolt turisztikai fejlesztésekre a fenntartható fejlődés, a szezonalitás csökkentésével a kiegyensúlyozott négy évszakos turizmus érdekében.

Melléklet :

A KUTATÁSBA VONT FÜRDóhELYEK FóBB JELLEMZŐI, IS MERTETÓJEGYEI

\begin{tabular}{|c|c|c|c|}
\hline Fürdóhely & $\begin{array}{c}\text { Bükfürdő: } \\
\text { Bükfürdő Gyógy- } \\
\text { és Élménycentrum }\end{array}$ & $\begin{array}{l}\text { Kehidakustány: } \\
\text { Kehida Termál Gyógy- } \\
\text { és Élményfürdő }\end{array}$ & $\begin{array}{c}\text { Lipót: } \\
\text { Lipóti Termál- és Élmény- } \\
\text { fürdő \& Camping**** }\end{array}$ \\
\hline Megye & Vas & Zala & Gyôr-Moson-Sopron \\
\hline Gyógyhely & 1979 & 2016 & nem \\
\hline OES kategória & nemzetközi & országos és regionális & helyi \\
\hline A víz jellemzôi & $\begin{array}{l}\text { alkáli-hidrogénes, magas } \\
\text { fluorid-, jodid- és vastartal- } \\
\text { mú víz }\end{array}$ & $\begin{array}{l}\text { kénes, kalcium-magnézi- } \\
\text { um-hidrogén-karbonátos } \\
\text { minôsítésû́ víz }\end{array}$ & $\begin{array}{l}\text { alacsony keménységú nát- } \\
\text { rium-hidrogén-karbonátos } \\
\text { fluoridos víz }\end{array}$ \\
\hline $\begin{array}{l}\text { Összes oldott } \\
\text { anyag }\end{array}$ & $15000 \mathrm{mg} / 1$ & $748 \mathrm{mg} / 1$ & $1394 \mathrm{mg} / 1$ \\
\hline Kútfúrás éve & $1957(1960)$ & 1977 & 1968 \\
\hline $\begin{array}{l}\text { A kút talpmély- } \\
\text { sége }\end{array}$ & $1282 \mathrm{~m}$ & $192 \mathrm{~m}$ & $2200 \mathrm{~m}$ \\
\hline A kút vízhozama & 9000 l/perc (1100 l/perc) & $7201 /$ perc & 1300 l/perc \\
\hline $\begin{array}{l}\text { Hévízkútból fel- } \\
\text { törô víz hôfoka }\end{array}$ & $58^{\circ} \mathrm{C}$ & $49{ }^{\circ} \mathrm{C}$ & $65^{\circ} \mathrm{C}$ \\
\hline
\end{tabular}




\begin{tabular}{|c|c|c|c|}
\hline Fürdóhely & $\begin{array}{c}\text { Bükfürdô: } \\
\text { Bükfürdő Gyógy- } \\
\text { és Élménycentrum }\end{array}$ & $\begin{array}{l}\text { Kehidakustány: } \\
\text { Kehida Termál Gyógy- } \\
\text { és Élményfürdó }\end{array}$ & $\begin{array}{c}\text { Lipót: } \\
\text { Lipóti Termál- és Élmény- } \\
\text { fürdő \& Camping**** }\end{array}$ \\
\hline $\begin{array}{l}\text { Gyógyvízzé } \\
\text { minôsítés éve }\end{array}$ & 1965 & 2002 & 2004 \\
\hline $\begin{array}{l}\text { Gyógyvízjaval- } \\
\text { latok }\end{array}$ & $\begin{array}{l}\text { valamennyi mozgásszervi } \\
\text { betegség, emésztôrend- } \\
\text { szeri panaszok, keringési } \\
\text { zavarok }\end{array}$ & $\begin{array}{l}\text { magas vérnyomás, reu- } \\
\text { matikus és mozgásszervi } \\
\text { panaszok, idegrendszeri } \\
\text { kórképek, bôrbetegségek } \\
\text { kezelése, Bechterew-kór }\end{array}$ & $\begin{array}{l}\text { kopásos ízületi és gerinc- } \\
\text { betegségek, ízületi gyulla- } \\
\text { dás kezelésére, valamint } \\
\text { balesetek mozgásszervi } \\
\text { szövôdményeinél }\end{array}$ \\
\hline Medencék & $34 \mathrm{db}$ medence & $13 \mathrm{db}$ medence & $5 \mathrm{db}$ medence \\
\hline Csúszdák & $\begin{array}{l}6 \text { db óriáscsúszda, } \\
1 \text { db gyermekcsúszda }\end{array}$ & $\begin{array}{l}3 \text { db óriáscsúszda, } \\
1 \text { db gyermekcsúszda }\end{array}$ & $6 \mathrm{db}$ óriáscsúszda \\
\hline $\begin{array}{l}\text { További vizes } \\
\text { szolgáltatások }\end{array}$ & $\begin{array}{l}\text { vizes játékpark és vízi játé- } \\
\text { kok, úszásoktatás }\end{array}$ & $\begin{array}{l}\text { ivókúra (Csend szoba, } \\
\text { gyógyfürdô), aromaolajos } \\
\text { kádfürdô, babaúszás }\end{array}$ & $\begin{array}{l}\text { vizes játékpark és vízi } \\
\text { játékok }\end{array}$ \\
\hline Szolgáltatások & $\begin{array}{l}\text { szaunavilág, szaunaszeán- } \\
\text { szok, masszázs, reumatoló- } \\
\text { giai szakrendelés, vendég- } \\
\text { látás, fürdôshop, manikûr, } \\
\text { pedikúr, játszószoba }\end{array}$ & $\begin{array}{l}\text { szaunaoázis, szaunasze- } \\
\text { ánszok, Csemete Kuckó, } \\
\text { vendéglátás, rendezvény- } \\
\text { szervezés/konferencia - } \\
\text { hotel, szolárium, fodrászat, } \\
\text { pedikúr, manikûr, kozme- } \\
\text { tikai szalon }\end{array}$ & $\begin{array}{l}\text { finn szauna (belépójegy } \\
\text { árában), masszázs, vendég- } \\
\text { látás, fürdôshop }\end{array}$ \\
\hline $\begin{array}{l}\text { Sportolási } \\
\text { lehetôségek }\end{array}$ & úszás, strandröplabda & $\begin{array}{l}\text { úszás, szabadtéri sakk és } \\
\text { lengôteke }\end{array}$ & $\begin{array}{l}\text { úszás, strandröplabda, } \\
\text { strandfoci, futball, tollas, } \\
\text { pingpong }\end{array}$ \\
\hline Programok & $\begin{array}{l}\text { ingyenes animációs prog- } \\
\text { ramok, Minimax Családi } \\
\text { Nap, Halmay Úszóverseny, } \\
\text { Strandok Éjszakája, Ma- } \\
\text { gyar Fürdókultúra Napja } \\
\end{array}$ & $\begin{array}{l}\text { aquafitness, gyermek- } \\
\text { animáció a Csemete } \\
\text { Kuckóban }\end{array}$ & $\begin{array}{l}\text { fôszezonban minden } \\
\text { szombaton és vasárnap } \\
\text { músorok és elôadások a } \\
\text { színpadon }\end{array}$ \\
\hline $\begin{array}{l}\text { Szállás a für- } \\
\text { dôvel } \\
\text { összekötve }\end{array}$ & $\begin{array}{l}\text { igen, } 1 \text { db kemping: } \\
166 \text { beállóhely, } 10 \text { db } \\
\text { hatszemélyes Aqua Camp } \\
\text { mobil ház, } 1 \text { db ötszemé- } \\
\text { lyes jurtasátor (a kemping } \\
\text { vendégei ingyenesen } \\
\text { igénybe vehetik a fürdôt), } \\
\text { valamint } 2 \text { db szálloda } \\
\text { (Hunguest Hotel Rép- } \\
\text { ce***, Hunguest Hotel } \\
\text { Répce Gold****) }\end{array}$ & $\begin{array}{l}\text { igen, } 1 \text { db szálloda: Kehida } \\
\text { Termál Hotel }{ }^{* * * *}(42 \mathrm{db} \\
\text { szoba, konferenciaterem) }\end{array}$ & $\begin{array}{l}\text { igen, } 1 \text { db kemping: } \\
120 \text { beállóhely, } 15 \mathrm{db} \\
\text { hatszemélyes mobil ház, } \\
6 \text { db kétszemélyes faház, } \\
14 \text { db négyszemélyes } \\
\text { hálókocsi (a kemping } \\
\text { vendégei ingyenesen } \\
\text { igénybe vehetik a fürdôt) }\end{array}$ \\
\hline $\begin{array}{l}\text { SZÉP-kártya- } \\
\text { elfogadóhely }\end{array}$ & igen & igen & nem \\
\hline
\end{tabular}


Printz-Markó Erzsébet-Albert Tóth Attila: Az egészségturizmus fogalomrendszerének...

\begin{tabular}{|c|c|c|c|}
\hline Fürdôhely & $\begin{array}{c}\text { Bükfürdō: } \\
\text { Bükfürdő Gyógy- } \\
\text { és Élménycentrum }\end{array}$ & $\begin{array}{l}\text { Kehidakustány: } \\
\text { Kehida Termál Gyógy- } \\
\text { és Élményfürdó }\end{array}$ & $\begin{array}{c}\text { Lipót: } \\
\text { Lipóti Termál- és Élmény- } \\
\text { fürdó \& Camping**** }\end{array}$ \\
\hline Egyéb & $\begin{array}{l}\text { Magyarország második } \\
\text { legnagyobb gyógyfürdôje, } \\
\text { Bük Thermal Natural Life } \\
\text { termékcsalád, Szín5-ös } \\
\text { kampány }\end{array}$ & $\begin{array}{l}\text { Gyermekterápia (sérült } \\
\text { központi idegrendszer } \\
\text { kezelése: kehidai gyógyvíz } \\
\text { + Petô-módszer konduktív } \\
\text { pedagógia + családbarát } \\
\text { környezet), csúszda hang- } \\
\text { és fényeffektekkel }\end{array}$ & $\begin{array}{l}\text { OnBike akció: }-50 \% \text { a } \\
\text { kerékpárral érkezőknek } \\
2012 \text { óta }\end{array}$ \\
\hline $\begin{array}{l}\text { Fürdók Nemzeti } \\
\text { Tanúsító Véd- } \\
\text { jegy minósítés }\end{array}$ & van & nincs & nincs \\
\hline $\begin{array}{l}\text { Fürdóvendégek } \\
\text { szavazása } \\
(2015-)^{10}\end{array}$ & $\begin{array}{l}\text { Az Év Fürdôje } 2017 \\
\text { (7. hely) } \\
\text { Az Év Fürdôje } 2016 \\
\text { (10. hely) } \\
\text { Az Év Fürdôje } 2015 \\
\text { (12. hely) }\end{array}$ & $\begin{array}{l}\text { Az Év Fürdője } 2017 \\
\text { (13. hely) } \\
\text { Az Év Fürdôje } 2016 \\
\text { (12. hely) }\end{array}$ & $\begin{array}{l}\text { Az Év Feltörekvô Fürdôje } \\
2015 \text { (13. hely) }\end{array}$ \\
\hline
\end{tabular}

Forrás: Saját szerkesztés Aquaprofit, 2007, www.bukfurdo.hu/, Csapó, 2016, ÁNTSZ, 2017b; Géher et al., 2016, http://kehidatermal.hu/, Kiss-Nagy, 2003, http://lipotfurdo.hu/, /www.termalfurdo.hu, https://azevfurdoje.hu/2017-top15, www.furdoszovetseg.hu/vedjegy/, Szántó, 2018 alapján

\section{JEGYZETEK}

1 Lipóti Termál- és Élményfürdő \& Camping hivatalos honlapja: http://lipotfurdo.hu/.

2 Bükfürdő Gyógy- és Élménycentrum hivatalos honlapja: www.bukfurdo.hu/.

3 Kehida Termál Gyógy- és Élményfürdô hivatalos honlapja: http://kehidatermal.hu/.

4 Turisztikai Szervezetek Nemzetközi Uniója: International Union of Official Travel Organizations (IUOTO).

Európai Fürdốszövetség: European Spa Association (ESPA).

6 Fürdốk Nemzeti Tanúsító Védjegy használatára vonatkozó jogosultsággal rendelkezô fürdôk. Magyar Fürdôszövetség, www.furdoszovetseg.hu/vedjegy/.

7 Nemzetközi Fürdôszövetség: International Spa Association (ISPA).

8 A szálláshelyeken a vendégek tartózkodása után fizetett idegenforgalmi adót tartalmazó országos listán a fôváros nem egy településként szerepel, hanem a budapesti kerületek külön-külön találhatók. Magyar Államkincstár, 2016-os adatok: Tartózkodás után fizetett idegenforgalmi adó önkormányzatonként, 2016-os éves beszámoló. (Igényelt adatok a Magyar Államkincstártól.)

9 REVPAR-mutató (Revenue per Available Room): egy kiadható szobára jutó szobaárbevétel. A szobaárbevétel és a kiadható szobák számának (kapacitásának) hányadosa, illetve kiszámítható a szobafoglaltság \%-os mutatójának és az átlagárnak a szorzatával. Egy mutatóban jeleníti meg a foglaltság és az átlagár együttes hatását. Az egyik legfontosabb szállodai (szálláshelyi) mutatószám, amely utal az adott szálláshely hatékonyságára, bevételtermelô képességére.

10 Eldőlt, melyik Az Év Fürdôje 2015-ben. Háttérinformációk, érdekességek, www.termalfurdo.hu/sajtokozlemeny/eldolt-melyik-az-ev-furdoje-2015-ben-hatterinformaciok-erdekessegek-11; Az Év Fürdője 2016 szavazás végeredménye, https://azevfurdoje.hu/top15; Az Év Fürdôje 2017 szavazás végeredménye, https://azevfurdoje.hu/2017-top15. 


\section{Polgári Szemle · 14. évfolyam 1-3. szám}

\section{FELHASZNÁLT IRODALOM}

Albel Andor - Tokaji Ferenc (2006): ALFÖLD SPA Gyógyítás és wellness a Dél-Alföld termálfürdôiben. Schneider Nyomda Kft., Gyula.

Albert Tóth Attila (2011): A magyar szállodaipar egészégturisztikai vonatkozásai. VI. KHEOPS Tudományos Konferencia tanulmánykötet, Mór, 379-388.

Albert Tóth, Attila (2016): The importance of Spa and Wellness Hotels in Leisure Destinations in Hungary. International Leisure Review, Vol. 5, No. 2, 3-29.

ÁNTSZ (2017a): Országos törzskönyvi nyilvántartás a magyarországi gyógyszállókról. Állami Népegészségügyi és Tisztiorvosi Szolgálat, február 7., www.antsz.hu/felso_menu/ugyintezes/hatosagi_nyilvantartas/termeszetes_gyogytenyezok_nyt/gyogyszallok.html?query=gy\%C3\%B3gysz\%C3\%A111\%C3\%B3.

ÁNTSZ (2017b): Országos Gyógyhelyi és Gyógyfürdôügyi Fóigazgatóság törzskönyvi nyilvántartás, OTH által elismert gyógyvizek jegyzéke. Állami Népegészségügyi és Tisztiorvosi Szolgálat, http://efrirb.antsz.hu:7778/ ogyfi/gyogyviz.jsp.

Aquaprofit (2007): Országos egészségturizmus fejlesztési stratégia. Aquaprofit Mûszaki, Tanácsadási és Befektetési Rt., Budapest.

Árpási Zoltán (2012): Wellness turisztikai szolgáltatások fejlesztésének lehetôségei a Dél-alföldi régióban. PhD-értekezés, Szent István Egyetem, Gazdálkodás- és Szervezéstudományok Doktori Iskola, Gödöllô.

Bakucz Márta - Tegzes Andrea (szerk.) (2016): Fürdôtelepülések versenyképességi vizsgálata néhány magyar és közép-európai régióban. Pécsi Tudományegyetem, Pécs.

Böjte Csaba (2013): A Fehér Szív Útja. Helikon Kiadó, Budapest.

Budai Zoltán - Székács Orsolya (2004): A magyar egészségturisztikai kínálat alakítása a különbözố célcsoportok igényei szerint. In: Aubert Antal - Csapó János (szerk): Egészségturizmus. PTE TTK Földrajzi Intézet, Pécs, 137-144.

Bywater, M. (1990): Spas and Health Resorts in the EC. EIU Travel and Tourism Analyst, No. 6, 52-67.

Czeglédi József (1999): A turizmus föbb termékei és szolgáltatásai. Külkereskedelmi Fóiskola, Budapest.

Csapó Tamás (fôszerk.) (2016): Bük Város monográfiája. Bük Város Önkormányzata, Bük.

Dunn, Halbert L. (1959): High-Level Wellness for Man and Society. American Journal of Public Health, Vol. 49, No. 6, 786-792.

Formádi Katalin (2008): Egészségturisztikai szakmák vizsgálata. Turizmus Bulletin, 11. évf., 4. sz., 34-45.

Géher Pál - Bender Tamás - Ákoshegyi György (2016): Magyarország gyógyfürdôi és gyógyvizes termálfürdôi. Magyar Balneológiai Egyesület, Budapest.

Happ Éva (2008): Wellnesshotel vagy konferenciaszálloda? In: Értékôrzés és értékteremtés. XI. Apáczai Napok 2007, Konferenciakötet, Gyôr, 500-509.

Kincses Gyula - Borbás Ilona - Mihalicza Péter - Udvardy Enikô - Varga Eszter (2009): Az orvosi szolgáltatásokra alapuló egészségturizmus tendenciái. Egészségügyi Stratégiai Kutatóintézet (ESKI), Budapest.

Kirschner, Christoph (2005): Glossar Europäischer Heilbäderverband. European Spas Association, Bad Homburg.

Kiss Veronika - Nagy Zoltán (szerk.) (2003): Magyar Fürdőalmanach. Magyar Fürdôszövetség, Országos Széchényi Könyvtár, Budapest.

Kenney, Patrick (2015): Wellness Tourism Taking the Vacation World by Storm. WRVO, 16 August, http:// wrvo.org/post/wellness-tourism-taking-vacation-world-storm\#stream/0.

KSH (2017): Turizmus, vendéglátás / Tájékoztatási adatbázis / Szálláshely szolgáltatás adatok. Központi Statisztikai Hivatal, Budapest, http://statinfo.ksh.hu/Statinfo/themeSelector.jsp?page=2\&szst=OGA.

Magyar Réka (2008): Spirituális turizmus I. A hit a legdrágább termék. Turizmus Trend, 1-2. sz., 12-14.

Márai Sándor (1943): Füves könyv. Révai Kiadó, Budapest (112: A fürdôzésrôl).

Michalkó Gábor (2012): Turizmológia. Elméleti Alapok. Akadémiai Kiadó, Budapest.

Molnár Csilla (2011): Az egészségturisztikai fejlesztések hatásai, különös tekintettel Kelet-Magyarországra. PhD-értekezés, Széchenyi István Egyetem, Regionális- és Gazdaságtudományi Doktori Iskola, Gyôr.

Mundruczó Györgyné - Szennyessy Judit (2005): A Széchenyi Terv egészségturisztikai beruházásainak gazdasági hatásai. Turizmus Bulletin, 9. évf., 3. sz., 30-41. 
Printz-Markó Erzsébet-Albert Tóth Attila: Az egészségturizmus fogalomrendszerének...

Mundruczó Györgyné - Pulay Gyula - Tököli László (2010): A turisztikai fejlesztések állami támogatása térségi és nemzetgazdasági szintú hatékonyságának vizsgálata. Állami Számvevôszék Kutató Intézete, Budapest.

Porter, Michael E. - Harryono, Monica - Huang, Yu-Feng Tom - Miyazawa, Koichi - Sethaput, Vijak (2006): Thailand Medical Tourism Cluster. Harvard Business School. Microeconomics of Competitiveness, 5 May, www.isc.hbs.edu/resources/courses/moc-course-at-harvard/Documents/pdf/student-projects/Thailand_Medical_Tourism_2006.pdf.

Printz-Markó Erzsébet (2016): Az egészségturizmus magyarországi rendszere a klaszterszervezódés összefüggésein keresztül. PhD-értekezés-tervezet, Széchenyi István Egyetem, Regionális- és Gazdaságtudományi Doktori Iskola, Gyôr.

Printz-Markó, Erzsébet - Darabos, Ferenc - Ivancsóné Horváth, Zsuzsa (2017): Dimensions of Wellness Tourism in Hungary. Knowledge Horizons - Economics, Vol. 9, No. 1, 24-35.

Rátz Tamara (2004): Zennis és Lomi Lomi, avagy Új trendek az egészségturizmusban. In: Aubert Antal Csapó János (szerk.): Egészségturizmus. Főiskolai jegyzet, PTE TTK Földrajzi Intézet, Pécs, 46-65.

Resiak-Urbanowicz, Marta - Printz-Markó, Erzsébet (2011): Vergleichsstudie der Gemeinsamkeiten und Unterschiede im Gesundheitstourismus von Polen und Ungarn. In: Kincs, ami van - Fókuszban az egészségturizmus. Konferenciakötet, Nyugat-magyarországi Egyetem, Győr, 104-120.

Ruszinkó Ádám (2006): Egészségturizmus I. Oktatási segédanyag a Heller Farkas Fơiskola Egészségturizmus Szakirány hallgatói részére.

Smith, Melanie - Puczkó László (2010): Egészségturizmus: gyógyászat, wellness, holisztika. Akadémiai Kiadó, Budapest.

Sziva Ivett (2010): Öntsünk tiszta vizet... Az egészségturizmus fogalmi lehatárolása és trendjeinek válogatott bibliográfiája. Turizmus Bulletin, 14. évf., 4. sz., 73-76.

Szántó Zoltán (2018): Magyar Fürdôszövetség - Az új elnök tervei. Turizmus.com, május 14., https://turizmus.com/szabalyozas-orszagmarketing/magyar-furdoszovetseg-az-uj-elnok-tervei-1157617.

Szántó Zoltán (szerk.) (2009): Szezonnyitó egészségturisztikai konferencia. Merre tovább?. Turizmus Trend, No. 7-8., 34-36.

Voleszák Zoltán (2000): A turizmus és a vendéglátás alapjai I. Vendéglátás-idegenforgalom szakmacsoport számára, 11. évfolyam, Szociális Foglalkoztató, Sopron. 